\title{
OTAKAR ŠOUREK - NEDOCENĚNÁ POSTAVA ČESKÉHO HUDEBNÍHO ŽIVOTA
}

\section{1. Úvod}

Jméno Otakara Šourka (1. 10. 1883 - 15. 2. 1956, Praha) je muzikologické obci dobře známo. Šourek je autorem dosud nejobsáhlejší čtyřdílné monografie o skladateli Antonínu Dvořákovi, napsal však také desítky knih a studií a několik tisíc článků a recenzí s rozmanitým hudebním zaměřením. Jeho profesní i osobní život byl bohatý. Jako voják zažil první světovou válku na východní frontě, konec Rakouska-Uherska, vznik samostatné Československé republiky, druhou světovou válku, únorový převrat 1948 i první roky komunistického režimu. Byl tak u přelomových historických okamžiků svého národa v první polovině 20. století, a stále veřejně činný a aktivní. Do denních listů, přispíval Šourek po desítky let i několikrát týdně, zachytil tedy nejen repertoár předních hudebních těles v proměnách času, ale také dobové estetické soudy.

Následující krátký příspěvek si klade za cíl představit hudebního spisovatele a kritika Otakara Šourka jako osobnost mnohem komplexnější, než je dnes muzikologickou obcí vnímán - tedy jako přední znalec své doby života a díla Antonína Dvořáka. ${ }^{1}$

Život, osobnost, význam a působení Otakara Šourka doposud nebyly podrobeny hlubšímu odbornému bádání. ${ }^{2}$ Slovníková hesla ${ }^{3}$ (z nichž nejobsáhlejší je

1 Předložená práce vznikla za finanční podpory Ministerstva kultury v rámci institucionálního financování dlouhodobého koncepčního rozvoje výzkumné organizace Národní muzeum (DKRVO 2015/49, 00023272) a navazuje na výzkum, který autorka podnikla a shrnula ve své diplomové práci Otakar Šourek (1883 - 1956) a jeho hudebně kritické působení, Katedra hudební vědy, FFUK, Praha, 2012.

2 Nejnovější př́spěvky $\mathrm{k}$ tomuto tématu viz pozn. 1, dále NOVÁ, Kateřina. Novinář a recenzent Otakar Šourek. Musicalia, 2011, r. 3, č. 1-2, s. 79-84, NOVÁ, Kateřina. Sondy do vztahu Václava Talicha a Otakara Šourka na pozadí jejich vzájemné korespondence. $H u$ dební věda, 2012, r. 49, č. 3, s. 301-320, NOVÁ, Kateřina. Sondy do vztahu Václava Talicha a Otakara Šourka na pozadí jejich vzájemné korespondence v letech 1939-1956 (dokončení). Hudebni véda, 2013, r. 50, č. 1-2, s. 145-178. 
Československý hudební slovník osob a institucíi ${ }^{4}$ přinášejí především stručný životopis a soupis Dvořákovské bibliografie, akcentují tedy především roli Šourka jako „dvořákologa“.

Během Šourkova života vyšlo při př́ležitosti jeho životních jubileí několik kratších časopiseckých textů. Nejrozsáhlejší a nejobsažnější je rozhovor se samotným Šourkem, publikovaný při př́ležitosti jeho 60 . narozenin. ${ }^{5}$ Zde se dozvídáme nejen o Šourkově názorech na hudební kritiku či o jeho vztahu k dílu Antonína Dvořáka, ale také některé podrobnosti z jeho života. Text hudebního publicisty Jana Löwenbacha, ${ }^{6}$ který obsahuje soupis hudebně-literárních prací O. Šourka, je rovněž důležitým zdrojem informací - i z toho důvodu, že jeho autor byl Šourkovým blízkým př́telem a můžeme tak předpokládat, že informace, $v$ textu obsažené, byly Šourkem verifikovány. Zajímavý je také text dirigenta Václava Talicha, věnovaný Šourkovým 70. narozeninám ${ }^{7}$ - komentuje nejen Šourkův život a činnost, ale i jejich prrátelství. Článek Antonína Hořejše je rovněž věnován Šourkovým sedmdesátým narozeninám a stručně shrnuje jeho dosavadní hudebně-publicistické působení. ${ }^{8}$

Z tohoto stručného výčtu je zřejmé, že publikované informace o životě a působení Otakara Šourka jsou zatím kusé, pro získání bližších informací je potřeba nahlédnout do Šourkovy pozůstalosti. Ta byla v průběhu let získána (darem i koupí) Národním muzeem - Muzeem Antonína Dvořáka. ${ }^{9}$

\section{2. Životopis}

Otakar Šourek se narodil dne 1. října 1883 v Praze do hudebně založené rodiny - jeho otec byl basistou a funkcionářem pražského Hlaholu, matka hrála na klavír.

London: Macmillan Publisher, 1980, s. 753-754. TYRRELL, John. Šourek, Otakar. in Grove Music Online. [databáze online]. Oxford University Press 2007-2012. [citováno 2015-223]. Dostupné z URL < http://han.nkp.cz/han/OxfordMusicOnline-GroveMusicOnline/www. oxfordmusiconline.com/subscriber/article/grove/music/26301?q=\%C5\%A0ourek\&sear$\mathrm{ch}=$ quick\&pos=1\&_start=1\#firsthit $>$. Text převzat z SLOMINSKY, Nicholas, ed.: Baker's Biographical Dictionary of Musicians, Vol. 5. New York: Schirmer Reference, 2001, s. 704. ŠTĚDROŇ, Bohumír. Šourek, Otakar. In KOL. RED.: Československý hudebni slovník osob a institucí. Svazek 2. Praha: Státní hudební vydavatelství, 1965, s. 714-715.

5 Jbk. K jubileu Otakara Šourka. Rytmus, 1943-1944, r. 9, č. 1, s. 2-7.

6 LÖWENBACH, Jan. Dvořákův životopisec. Tempo: Listy Hudebni matice. 1933, r. 13, č. 2 , s. $35-40$.

$7 \quad$ TALICH, Václav. Úvahy, projevy a stati. Beroun: Okresní muzeum v Berouně, 1983, s. 134 137.

8 HOŘEJŠ, Antonín. Jubileum Otakara Šourka. Hudební rozhledy. 1953, r. 6, č. 14, s. 654.

9 Pozůstalost Otakara Šourka, která je součástí rozsáhlé pozůstalosti Jarmila Burghausera (obě pozůstalosti se v současné době zpracovávají), je v Národním muzeu - Muzeu Antonína Dvořáka (dále NM-MAD) uložena pod př́růstkovými čísly 88/98, 1/99, 85/2000. 
Sám Šourek byl v hudbě především samoukem. Po studiu na reálném gymnáziu v letech 1894-1901 nastoupil na Vysokou školu technickou v Praze, obor stavební inženýrství, kterou ukončil v roce 1906. Hru na klavír a hudební teorii studoval u Markarie Svobodové, žačky Zdeňka Fibicha a u hudebního teoretika, skladatele a pedagoga Karla Steckera. Na univerzitě byl členem Akademického orchestru, ${ }^{10}$ kde hrál na lesní roh, jako sbormistr působil dva roky v Technickém pěveckém sboru (od r. 1902), posléze v pěveckém a hudebním sdružení Smetana (1905-1906). Po univerzitních studiích v roce 1907 nastoupil na pražský regulační úřad. Od roku 1931 působil na pozici vrchního stavebního rady na ředitelství technické služby obecní, odkud roku 1939 odešel do výslužby. Po celou dobu své úřednické kariéry Šourek žil velmi aktivním veřejným a spolkovým životem. Jako hudební recenzent

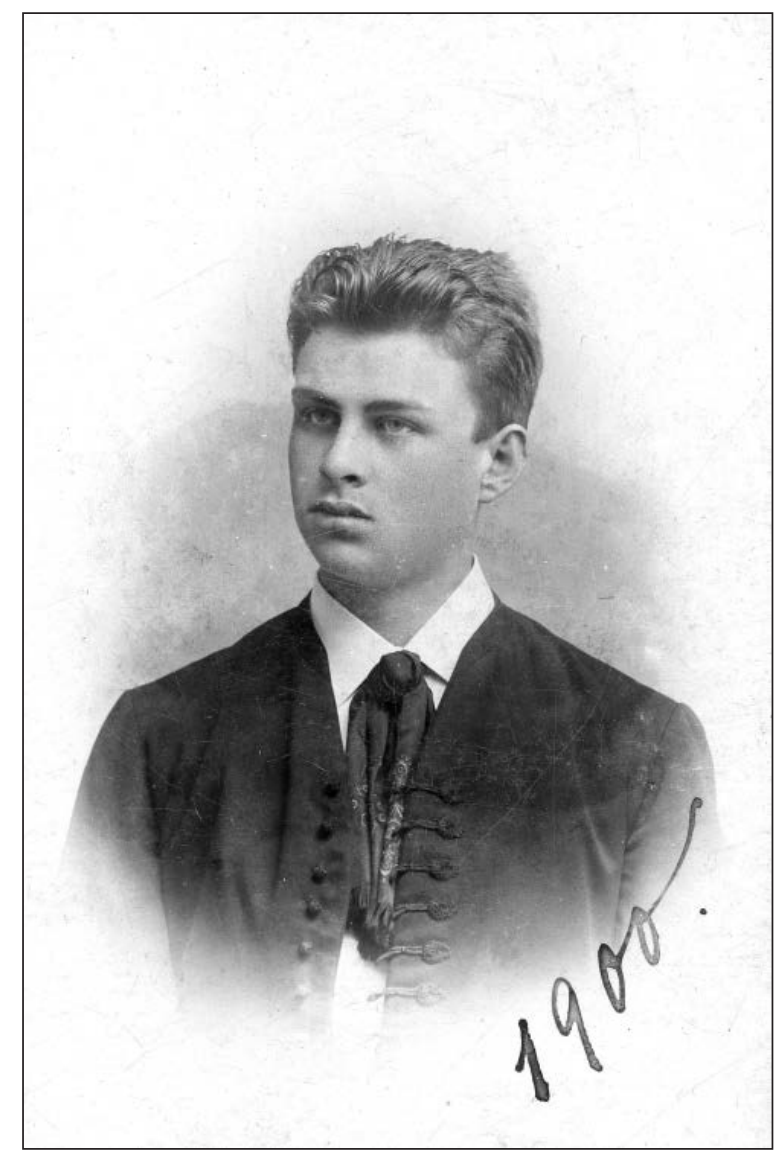

Obr. 1. Otakar Šourek v roce 1900. Zdroj: Národní muzeum - Muzeum Antonína Dvořáka, č. př. $88 / 98$.

10 První symfonický amatérský orchestr, složen z posluchačů vysokých škol, vznik1 v roce 1897. 
prrispíval do řady periodik, pracoval na svých knihách, byl členem mnoha hudebních organizací. Právě těmto jeho aktivitám je věnován následující text.

\section{3. Šourek - Dvořákolog}

Jak bylo zmíněno shora, Otakar Šourek je dodnes odbornou veřejností vnímán především jako přední znalec života a díla Antonína Dvořáka. Šourkova zakladatelská role ve dvořákovském bádání je nezpochybnitelná. Šourek se výzkumu a propagaci díla Antonína Dvořáka obětavě věnoval po celý život. Výsledky svého bádání Šourek průběžně publikoval jak v periodických tak i neperiodických publikacích.

Šourkovo odborné směřování určil pravděpodobně časopis Hudební revue, který Šourkovi zadal na jaře 1910 jeho první větší úkol, totiž vytvořit edici dopisů Antonína Dvořáka adresovaných jeho moravskému př́znivci a podporovateli Emilu Kozánkovi. ${ }^{11}$ Následovala celá řada dalších, hlubších dvořákovských studií, ${ }^{12}$ jež byly vlastně př́ípravou pro první díl jeho celkem 4 svazkové rozsáhlé monografie „Život a dílo Antonína Dvořáka“ (studie z let 1913 - 1916 se dají chápat také jako Šourkův prŕspěvek k tzv. Boji o Antonína Dvořáka ${ }^{13}$ ). V roce 1916 pak vydal u Hudební matice první díl (druhé vydání vyšlo u stejného nakladatelství v roce 1922, třetí vydání potom u Státního nakladatelství krásné literatury, hudby a umění v roce 1954), rok poté následoval druhý díl (druhé vydání u HMUB v roce 1928, třetí u SNKLHU v roce 1955), v roce 1930 byl hotov díl třetí (druhé vydání již pouze u SNKLHU v roce 1956) a v roce 1933 vyšel poslední, tedy čtvrtý díl (druhé vydání u SNKLHU, 1957). V roce 1917 Šourek vydal seznam Dvořákových skladeb, ${ }^{14}$ jenž se stal základem pro pozdější vydá-

11 ŠOUREK, Otakar. Dopisy Ant. Dvořáka Dru Emilu Kozánkovi v Kroměříži, Hudebni revue, r. 3, č. 6, červen 1910, s. 298-305, č. 7, červenec 1910, s. 345-349, č. 8, ř́jjen 1910, s. 398-403.

12 ŠOUREK, Otakar. Z Dvořákových dopisů nakladateli Simrockovi, Hudební revue, r. 4, č. 8-9, ř́jen 1911, s. 448-461. ŠOUREK, Otakar. Dvořákovy „Moravské dvojzpěvy“, Hudební revue, r. 6, č. 2, listopad 1913, s. 80-82. ŠOUREK, Otakar. První dvě skladby Dvořákovy. Hudebni revue, r. 7, č. 8, květen 1914, s. 364-376. ŠOUREK, Otakar. Úvodem k seznamu veškerých skladeb Antonína Dvořáka. Hudebni revue, r. 7, č. 8, květen 1914, s. 393-400. ŠOUREK, Otakar. Genese Dvořákova díla, Hudební revue. Hudební revue, r. 8, č. 1, leden 1915, s. 18-23, č. 4, duben 1915, s. 121-130, č. 5, květen 1915, s. 162-167, č. 6, červen 1915, s. 218-230, č. 7, červenec 1915, s. 249-257, r. 9, č. 4, leden 1916, s. 121-127, č. 5, únor 1916, s. 157-162, č. 6, březen 1916, s. 198-204, č. 7, duben 1916, s. 250-255, č. 8-9, květen - červen 1916, s. 318-322, č. 10, červenec 1916, s. 362-368; ŠOUREK, Otakar. O americké tvorbě Ant. Dvořáka, Listy Hudebni matice, r. 2, č. 7, 20. 4. 1923, s. 154-158, č. 10, 1. 7. 1923, s. 221-232.

13 Více k tomuto tématu viz PEČMAN, Rudolf. Útok na Antonína Dvořáka. Brno: Filozofická fakulta Masarykovy univerzity, 1992 nebo OTTLOVÁ, Marta. The"Dvořák Battles" in Bohemia: Czech Criticism of Antonín Dvořák, 1911-1915. In: Rethinking Dvořák. Views from Five Countries. BEVERIDGE, David R. (ed.). Oxford: Clarendon Press, 1996.

14 ŠOUREK, Otakar. Dvořák's Werke: Ein vollständiges Verzeichnis in chronologischer, thematischer Anordnung = Skladby Dvoŕákovy: Úplný seznam chronologický, thematický a systematický. Berlin: Simrock, [1917]. 
ní Burghauserova tematického katalogu. ${ }^{15}$ Mezi další významné publikace patří naprííklad „Dvořák ve vzpomínkách a dopisech“, která česky vyšla v Topičově edici v roce 1939 (druhé vydání Orbis, 1951), německy a anglicky v roce 1954 u vydavatelství Artia, dále výběr z korespondence „Antonín Dvořák svým přátelům doma“ z roku 1941, „Dvořákovy skladby komorní“ (vyšlo česky, anglicky a německy) či dva díly publikace „Dvoř́kovy skladby orchestrální“ ${ }^{\prime 16}$ Za svou publikaci „Antonín Dvoř́ák“ z roku $19299^{17}$ a za svou dosavadní vědeckou a propagační činnost získal Otakar Šourek v roce 1929 od ministra školství a národní osvěty Antonína Štefánka Státní cenu pro hudební umění a teorii. ${ }^{18}$

Šourek se o propagaci díla Antonína Dvořáka staral nejen perem, ale také organizační prací. Když byl dne 29. 3. 1931 založen Spolek pro postavení pomníku Mistra Ant. Dvořáka v Praze, ${ }^{19}$ byl Otakar Šourek jedním ze spoluzakladatelů. Dalšími členy byli mimo členů Českého kvarteta také Jan Branberger, Hugo Boettinger, Rudolf Karel, Vítězslav Novák či Roman Veselý. Společnost si předsevzala za cíl chránit a šírit odkaz Antonína Dvořáka. Vzhledem k zájmovému zaměření Šourka je jasné, že se ve společnosti aktivně angažoval, byl jeho místopředsedou..$^{20}$ Dne 20. června 1932 za výrazného přispění Otakara Šourka a J. M. Květa otevřela Společnost v pražské ulici Ke Karlovu Muzeum Antonína Dvoráka. ${ }^{21}$ Za jeho předsednictví navázal vydavatelský odbor společnosti úzkou spolupráci se Státním nakladatelstvím krásné literatury, hudby a umění, se kterým spolupracoval na souborném vydání Dvořákova díla. V roce 1950 byla z tohoto důvodu zř́zena v rámci Dvořákovy společnosti komise, jejímž byl Šourek předsedou. Úkolem komise bylo edici kriticky připravit. Dalšími členy komise byli František Bartoš, Jan Hanuš, Jiří Berkovec, Jarmil Burghauser, Antonín Čubr, Ladislav Láska, Antonín Pokorný a Karel Šolc. Vydávání bylo zahájeno r. 1954, do roku 1963 pak vyšlo na 106 Dvořákových skladeb. Význam Otakara Šourka pro dvořákovské bádání shrnul ve svém textu Antonín Hořejš: Otakar Šourek

15 BURGHAUSER, Jarmil. Antonín Dvořák. Tematický katalog. Bibliografie, přehled života a dílo. 2. vyd. Praha: SNKLHU, 1960.

16 DVOŘÁK, Antonín a ŠOUREK, Otakar, ed. Antonín Dvořák př́telům doma. Praha: Melantrich, 1941; ŠOUREK, Otakar. Dvoŕákovy skladby komorní: charakteristika a rozbory. Praha: Hudební matice Umělecké besedy, 1943; ŠOUREK, Otakar. Dvořákovy skladby orchestrálni: charakteristika a rozbory. [Svazek] I., Koncerty - serenády - suity - nokturna - rhapsodie - slovanské tance - legendy - symfonické variace - scherzo capriccioso - skladby drobné. Praha: Hudební matice Umělecké besedy, 1944; ŠOUREK, Otakar. Dvořákovy skladby orchestrálni: charakteristiky a rozbory. [Svazek] II., Skladby programni. Ouvertury operní ouvertury koncertni - symfonické básně. Praha: Hudební matice Umělecké besedy, 1946. ŠOUREK, Otakar. Antonín Dvořák. Praha: Mánes, 1929.

18 [Výroční státní ceny pro hudební umění a teorii], Tempo: Listy Hudební matice, r. 9, č. 3, 20. 11. 1929, s. 122. Od roku 1944 se název zjednodušil na Společnost Antonína Dvořáka.

20 HALLOVÁ, Markéta. 75 let Společnosti Antonína Dvořáka, Hudebni rozhledy, 2006, r. 59, č. 3, s. 45 .

21 Šourek pracoval pro pražský magistrát a dokázal získat pronájem budovy muzea za symbolickou cenu jedné koruny. Viz pozn. 20. 


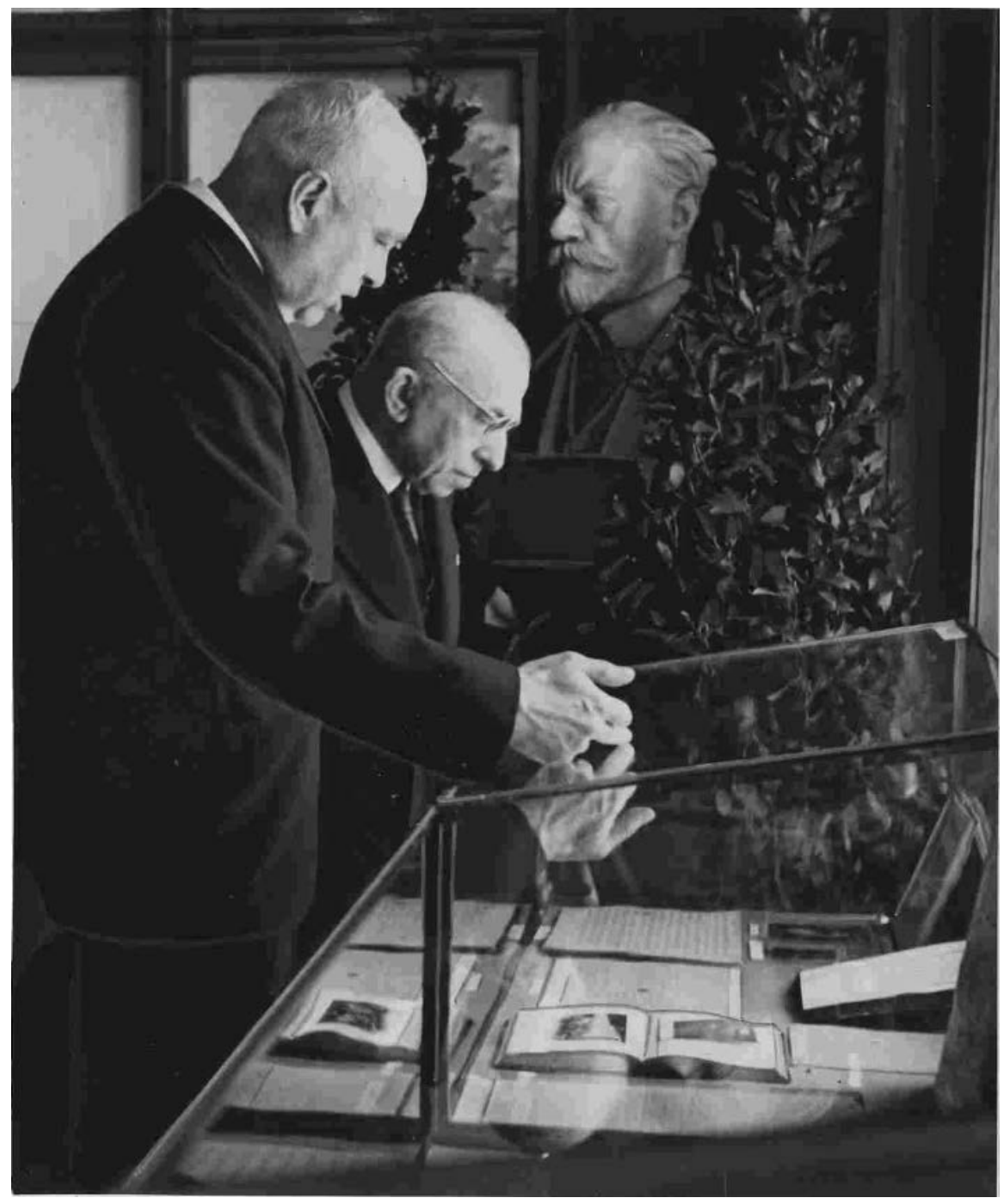

Obr. 2. Otakar Šourek a státní prezident Emil Hácha na výstavě Antonín Dvořák, pravděpodobně v Ústřední knihovně hl. m. Prahy (dnes Městská knihovna v Praze Ústřední knihovna). Zdroj: Národní muzeum - Archiv Národního muzea.

„několik desitek let střežil [Dvořákovo] dílo, podnikal pátrání po každém jeho zlomku, shromažd'oval ho, popisoval a láskyplně ho přibližoval českému lidu."22

Ačkoliv se Šourek dvořákovskému bádání a propagaci Dvořákovy hudby věnoval po celý život, nebyly to rozhodně jediné jeho aktivity na poli hudby. Právě tyto další, „nedvořákovské“ aktivity jsou dnes méně známé či zcela neznámé. Šourek patřil ve své době mezi přední hudební kritiky, jako hudební spisovatel 
se věnoval nejen Dvořákovi, ale také jeho žákům a interpretům, ale i dalším významným českým skladatelům. Neméně významnou oblastí Šourkových aktivit je jeho veřejné působení v řadě hudebních institucí.

\section{4. Šourek - hudební kritik}

Dráhu hudebního kritika a referenta zahájil Šourek v roce 1906 krátkými př́ispěvky do časopisu Smetana, v té době v redakci Jana Branbergra. ${ }^{23}$ Od založení Hudební revue roku 1908 spolupracoval dlouhodobě také s tímto významným hudebním listem, prrispíval také do periodik Samostatnost, Rozvoj, brněnských Lidových novin. Když však Šourek četl v roce 1918 dopis od Jaroslava Hilberta, ${ }^{24}$ ve kterém ho odesílatel vyzval $\mathrm{k}$ prrijetí pozice hudebního referenta v novinách

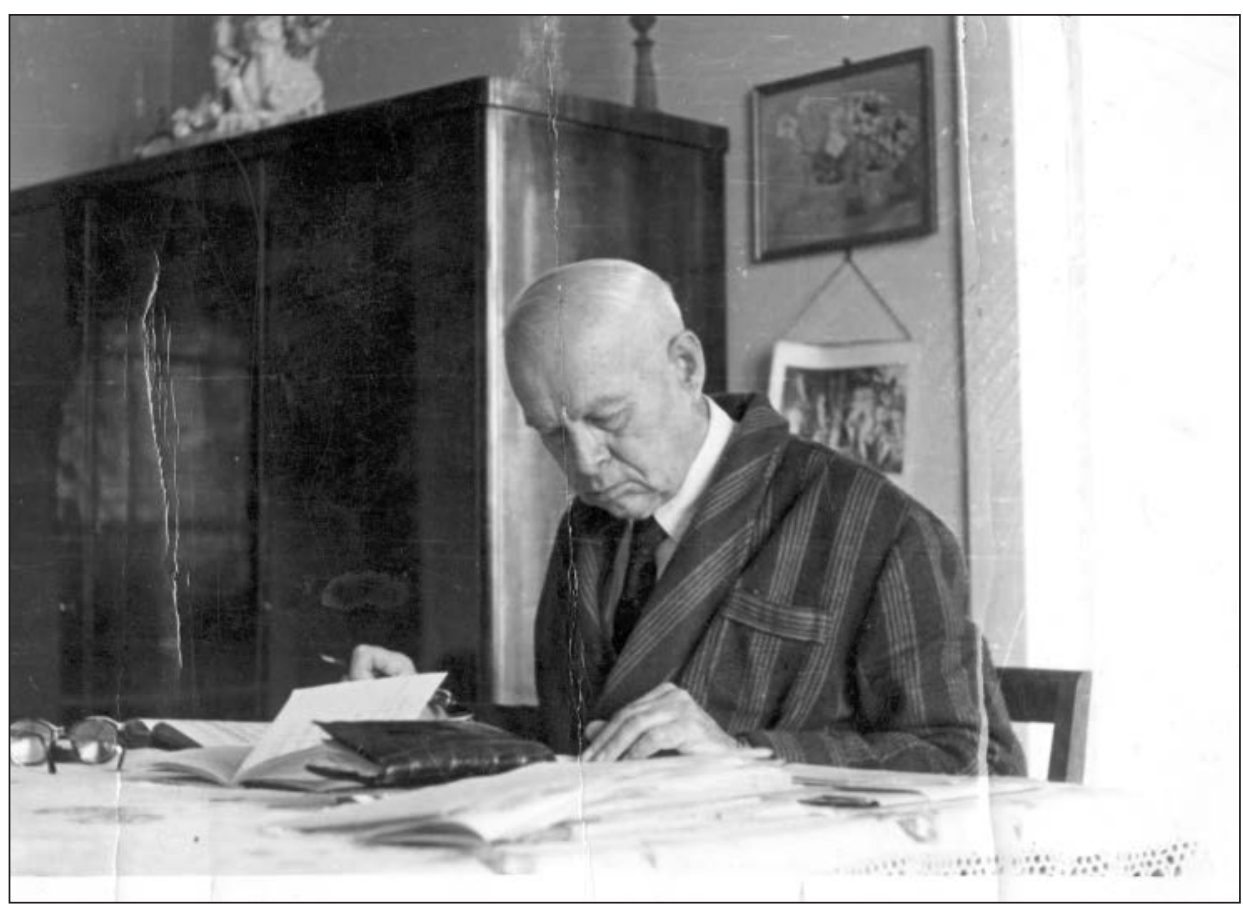

Obr. 3. Otakar Šourek u pracovního stolu. Zdroj: Národní muzeum - Muzeum Antonína Dvořáka, č. pr. $88 / 98$.

23 Jan Branberger (1877-1952) - hudební vědec, organizátor, působil na Pražské konzervatoři, později na Ministerstvu školství a národní osvěty, vyvíjel činnost redaktorskou, ediční a hudebně historickou.

24 Hilbert, Vladimír. Šourek, Otakar, Praha, 16. 12. 1918, uložen v NM-MAD, č. př. 88/98. Jaroslav Hilbert (1871-1936) - dramatik a spisovatel, po 30 let psal divadelní kritiky pro noviny Venkov. 
Republikánské strany zemědělského a malorolnického lidu Venkov, jistě Šourek netušil, že svým souhlasem navazuje spolupráci, která bude trvat úctyhodných 23 let. Hilbert v dopise nabízí Šourkovi následující podmínky - odměnu 60 haléřů za rádek textu, volná místa v Národním divadle, proplacení dalších koncertů, stejně jako hudebních knih a materiálů. Šourek s Venkovem spolupracoval až do roku 1941, kdy se vzdal pozice hudebního referenta, př́ležitostně však s novinami i nadále spolupracoval. Během svého referentského působení do Venkova přispíval několikrát týdně, z valné většiny kritikami koncertů a operních představení; celkem to za dobu jeho působení v novinách Venkov čítá na tisíce př́spěvků.

Šourek se dovedl, ,z praktického hudebnika dlouholetou a houževnatou výchovou vypracovati na odborného hudebniho spisovatele a kritickou osobnost úctyhodné erudice a ušlechtilé literárni formy." ${ }^{25}$

\section{5. Šourek - hudební spisovatel}

Otakar Šourek zanechal v českém hudební literatuře hlubokou stopu nejen svými dvořákovskými publikacemi. Je autorem desítek dalších monografií, zabýval se především Dvořákovými žáky, současníky, interprety, ale i dalšími výraznými postavami českého hudebního života.

Ze Šourkových nedvořákovských publikací dlužno zmínit několik časopiseckých pracích o Josefu Sukovi ${ }^{26}$ a Vítězslavu Novákovi, ${ }^{27}$ publikace o Rudolfu Karlovi, ${ }^{28}$ dílech Bedřicha Smetany ${ }^{29}$ či Leoše Janáčka. ${ }^{30}$ Šourek také editoval sborník, vydaný při př́ležitosti narozenin dirigenta a př́tele Václava Talicha. ${ }^{31} \mathrm{O}$ tom, že se nevyhýbal ani soudobé hudbě nejmladší generace svědčí fakt, že jeho první větší studie, publikovaná již v roce 1906 byl rozbor symfonie A dur Otakara Ostrčila. ${ }^{32}$

25 Viz pozn. 6 , s. 36.

26 ŠOUREK, Otakar. Sukovy melodramatické pohádky. Hudebni revue, 1912, r. 5, č. 7, s. 312; ŠOUREK, Otakar. Skladby Josefa Suka. Hudební revue, r. 7, č. 4-5, leden - únor 1914, s. 186-198. ŠOUREK, Otakar. Jos. Suk o svém tvưrčím vývoji. Tempo: Listy Hudební matice, 1934, r. 13, č. 5, s. 142-145; ŠOUREK, Otakar. Stopami Sukova Epilogu. Tempo: Listy Hudebni matice, 1946, r. 18I, č. 2-3, s. 35-39 a č. 4-5, s. 120-124.

27 ŠOUREK, Otakar. Skladby Vítězslava Nováka, Hudebni revue, r. 3, č. 10, prosinec 1910, s. 507-516.

28 ŠOUREK, Otakar. Rudolf Karel: Variace v životě i díle. Vydání 1. Praha: Hudební matice Umělecké besedy, 1947.

29 ŠOUREK, Otakar, ed. Smetanova „Má vlast“: její vznik a osudy. Praha: Topičova edice, [1940].

30 ŠOUREK, Otakar. Leoš Janáček: Výlety páně Broučkovy: Rozbor. Praha: Hudební matice Umělecké besedy, 1920.

31 ŠOUREK, Otakar, ed. Václav Talich: život a práce: soubor statí. Praha: Hudební matice Umělecké besedy, 1943.

32 ŠOUREK, Otakar. Tematický rozbor Symfonie A dur O. Ostrčila, Smetana, 1906, r. 1, č. č. 6, 1. 3. 1906, s. 73-79. 


\section{6. Šourek jako veřejně činná osobnost}

Ačkoliv se Otakar Šourek živil jako úředník hl. města Prahy, svou lásku k hudbě aktivně projevoval ve svém volném čase. Ten rozděloval mezi mnohé funkce a aktivity v hudebních (ale i nehudebních) spolcích a institucích.

Jakožto uznávaný hudební kritik a spisovatel byl Šourek jmenován členem poradního sboru hudebního odboru Ministerstva školství a národní osvěty. Zde působil také v porotě pro udělování státní ceny mladým skladatelům, jako člen znaleckého sboru dlouhodobě s ministerstvem spolupracoval (především ve věci výkupu pozůstalosti A. Dvořáka od firmy Simrock). ${ }^{33}$

Spolek Umělecká beseda byla založena roku 1861 a od svého vzniku sdružovala nejvýznamnější osobnosti československé kultury. Otakar Šourek byl jejím členem od roku 1907, od roku 1912 stř́ídavě ve funkci knihovníka, archiváŕe, náhradníka, angažoval se v pedagogické sekci Hudební matice, v její vydavatelské komisi, byl členem správního výboru hudebního odboru Umělecké besedy, správcem sbírek, referentem prrijímací komise. Od roku 1927 byl spolu s Václavem Štěpánem místopředsedou hudebního odboru (předsedou byl tato léta hudební skladatel Ladislav Vycpálek). ${ }^{34}$ Ve vydavatelství Hudebního odboru Umělecké besedy publikoval Šourek celou řadu svých prací (viz text výše).

Ve stejném roce, jako v Umělecké besedě, tedy v roce 1912, započal svou spolupráci s Českým spolkem pro komorní hudbu, založeného již roku 1894 v Praze. Od roku 1917 zde zastával celou řadu funkcí - nejprve byl náhradníkem, později členem správní rady, jednatelem a poté po mnoho let až do své smrti předsedou správního výboru (v letech 1945-1956). ${ }^{35}$

Otakar Šourek nepolevil ve své aktivitě ani za nacistické okupace, kdy již opustil své civilní zaměstnání a odešel do penze. $O$ to více se tak mohl věnovat své vášni - hudbě. V Protektorátu Čechy a Morava existovala pouze jediná česká legální politická strana - Národní souručenství. Ustanovena roku 1939, byla $\mathrm{v}$ podstatě jedinou legální pasivní rezistencí vůči nacistické okupační správě. Snahou Národního souručenství bylo v daných podmínkách zajistit alespoň nějaké fungování Československa. ${ }^{36}$ Součástí Národního souručenství byla také Kulturní rada, rozdělená do 12 sekcí. Předsedou Kulturní rady byl historik a literární kritik Miloslav Hýsek, místopředsedou houslista Jan Kubelík. Devátá sekce rady byla sekce hudební a divadelní. Jejím předsedou byl Otakar Šourek, místopředsedou

33 Jak vyplývá z korespondence O. Šourka s Ministerstvem školství a národní osvěty, uloženo v NM-MAD, č. př. 88/98.

34 SKÁCEL, František. Sedmdesát let Umělecké besedy. 1863-1933. Praha: Umělecká beseda, 1933.

35 Viz „ČF. Protokoly ze schůzí ČSKH - KPH 1901-64. Seznamy členů 1894-1907, 1930. Materiály o členech 1935-1939“, uloženo v Národním archivu v Praze, 5. odd., ka. 2.

36 VEČEǨA, Pavel. Národní souručenství, in: Politické strany: vývoj politických stran a hnuti $v$ českých zemich a Československu v letech 1861-2004, Malír̆, Jiří a kol. Brno: Doplněk, 2005, s. 1091-1103. 
potom Emil Axman. ${ }^{37}$ Hudební sekce během doby okupace zorganizovala desítky hudební akcí a událostí. Mezi ty nejvýznamnější patřily bezesporu Český hudební máj v roce 1940 a Jubilejní rok Antonína Dvořáka v roce $1941 .{ }^{38}$ Otakar Šourek se angažoval během obou událostí, z pozice znalce hudby Antonína Dvořáka byl ale přece jen aktivnější v roce 1941. Byl předsedou pracovního výboru Dvořákova jubilejního roku, z velké části celou akci organizoval a koordinoval, sám se aktivně jako řečník účastnil řady koncertů a ceremonií, přednášel o Antonínu Dvoř́kovi v mnoha českých a moravských městech. ${ }^{39}$

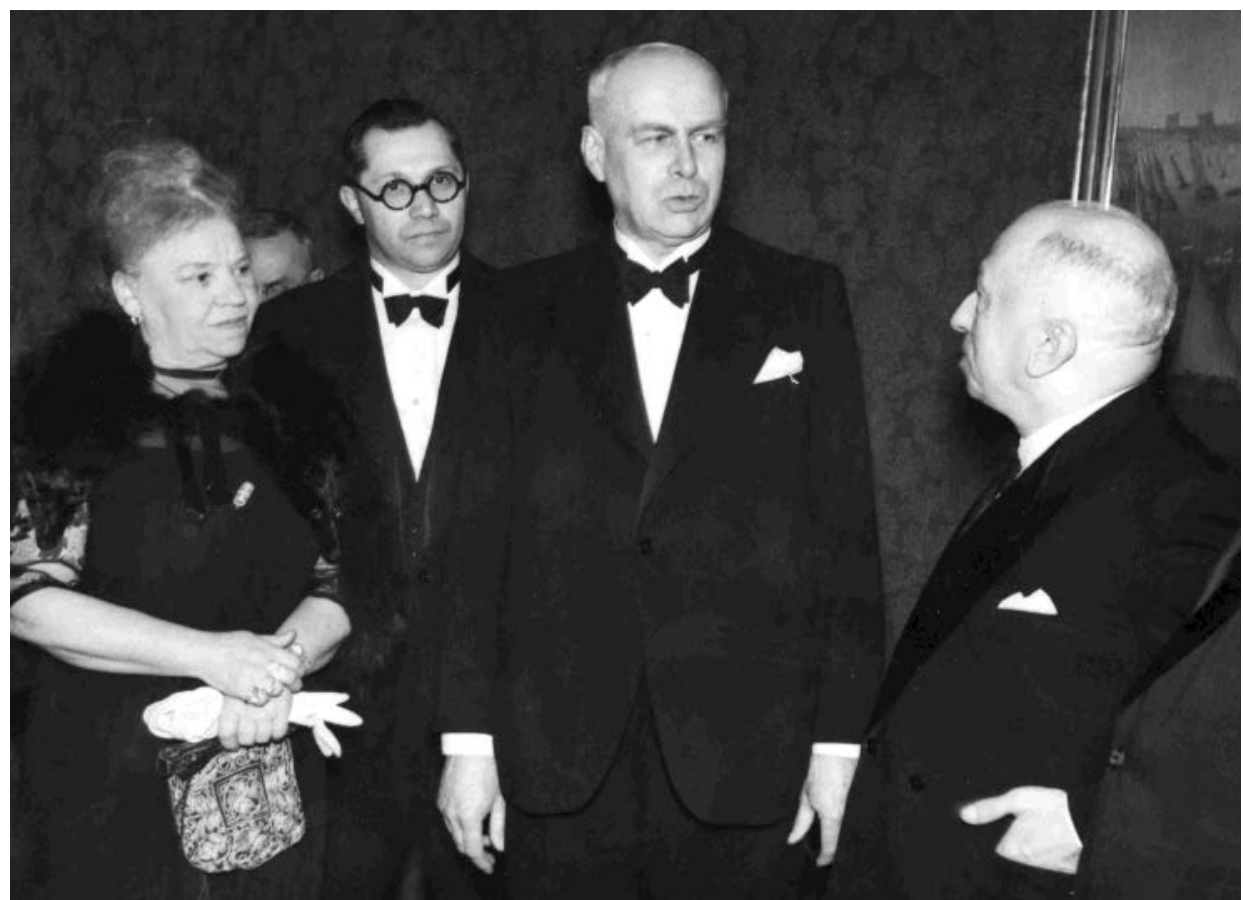

Obr. 4. Zahajovací koncert Dvořákova jubilejního roku, Smetanova síň Obecního domu v Praze, zprava státní prezident Emil Hácha, Otakar Šourek, vpravo Julie Dvořáková. Zdroj: Národní muzeum - Muzeum Antonína Dvořáka, č. př. 88/98.

37 MIKOTA, Václav, ed. Hudba a národ. V Praze: Svaz českých knihkupců a nakladatelů, 1940, s. 22-23.

38 Více k Dvořákově jubilejnímu roku viz NOVÁ, Kateřina. Dvořákův jubilejní rok 1941. Musicalia, 2014, r. 6, č. 1-2, s. 39-52.

39 Jak vyplývá ze spisu „Kulturní rada“, uloženo v Archivu kanceláře prezidenta republiky, inv. č. 1281/D, sign. S 11 534/44. kart. 213 a Šourkovy korespondence, uloženo v NM-MAD, č. př. 88/98. 


\section{7. Šourek a jeho přátelé}

Jakožto osoba veřejně velmi aktivní měl Otakar Šourek řadu přátel a známých z oblasti hudby. Mnohé prátelství mělo svi̊j původ v tzv. Podskalské filharmonii, neformálního uskupení amatérských i profesionálních milovníků hudby (nejen muzikantů, ale také výtvarníků, literátů a intelektuálů, podnikatelů), založeného roku 1900 skladatelem Vítězslavem Novákem. Otakar Šourek byl členem užšího výboru. Společnost se scházela několikrát do týdne, aby si přehrála novinky soudobých českých i světových skladatelů, pořádala večírky, byla zdrojem poznání a inspirace pro všechny členy. Počet členů se pohyboval kolem 60 osob, mezi nimi např. skladatelé Jaroslav Křička, Ladislav Vycpálek, Josef Suk, Otakar Šín, dirigent Václav Talich, klavírista a pedagog Karel Hoffmeister, klavírista Jan Heřman, Václav Štěpán, Vladimir Rebikov, hudební spisovatel Richard Veselý, výtvarník Hugo Boettinger, hudební spisovatel a organizátor Boleslav Schnabel-Kalenský, podnikatel Adolf Schwerak, dirigent Vincenc Maixner ad. ${ }^{40}$ Již v té době můžeme vystopovat zárodky rozdělení české hudební veřejnosti na dva póly, které se později plně projevily v tzv. bojích o Dvořáka, tedy zjednodušeně řečeno na stranu Zdeňka Nejedlého a proti Nejedlému. V tomto seskupení hudebních nadšenců lze vysledovat vztahy a vazby mezi jednotlivými osobnostmi, které i v pozdějších hudebních „kauzách“ a „aférách“ hrály svou roli. ${ }^{41}$

Přátelství Václava Talicha (1883-1961) doprovázelo Otakara Šourka po téměř celý život, více než 40 let. Přečkalo rozpad Rakouska-Uherska, první republiku, nacistickou okupaci i komunistický převrat; úspěchy i pády obou mužů. Jejich vztah začal již v roce $1905 .{ }^{42}$ Šourek dirigoval pěvecký sbor Smetana, o rok později ale musel nastoupit na povinnou vojenskou službu a přenechal tuto funkci právě Václavu Talichovi. O povaze jejich přátelství si můžeme udělat obrázek jednak díky dochované korespondenci ${ }^{43}$, ale také díky textům, veřejně publikovaným. ${ }^{44}$ Šourek jako hudební kritik Václava Talicha vždy obdivoval a podporoval. Ten si zase velmi cenil Šourka stř́zlivého úsudku a nejednou jej žádal o radu či

40 BAJEROVÁ, Blanka. V. Novák, J. Suk a Podskalská filharmonie. [online]. Dostupné z: $<$ http://www.suksociety.cz/odbisp/CL_bajerova.htm>, [citováno 2015-2-23]. Kronikář spolku Richard Veselý sepsal dějiny Podskalské filharmonie, dochovaly se v rukopise v jeho pozůstalosti v držení varhanice Aleny Veselé (Brno).

41 Např. v kauze nástupu Václava Talicha do čela České filharmonie nebo v tzv. Sukově afére, kdy v roce 1918 Zdeněk Nejedlý zaútočil na morální integritu nejen Josefa Suka, ale celého Českého kvarteta.

42 TALICH, Václav. Úvahy, projevy a statě. Beroun: Okresní muzeum Beroun, 1983, s. 134.

43 V Talichově pozůstalosti, která je deponována v Okresním muzeu Beroun (inv. č. T 1277-T 1284. T 1812, T 2394, T 2399, T 2473, T 2475-T 2480, T 3573, Т 3575, T 3674, T 3804 T3805), je uložena korespondence odeslaná Otakarem Šourkem z rozmezí let 1933 až 1955, celkem 23 dopisů. Šourkova pozůstalost, uložena pod př. Č. 88/98 v NM-MAD, je bohatší. Obsahuje celkem 122 jednotek - dopisy, pohledy, přání ad. od Talicha či jeho rodiny, koncepty či průklepy Šourkových dopisů Talichovi a některé další dokumenty. $Z$ valné většiny jsou dopisy psány rukou, méně na psacím stroji, jsou datovány a lokovány.

Viz pozn. 42. 
pomoc. ${ }^{45} \mathrm{O}$ tom, jaké city choval Talich $\mathrm{k}$ Šourkovi, svědčí i jeho oslavná řeč, kterou Talich pronesl při př́ležitosti Šourkových 70. narozenin, dne 1. října 1953: „Drahý Otićku, běžel jsem vytrvale svuij běh. Ted' už za sebou nohy jen vleču. Nejraději bych oslavil Tvoji sedmdesátku několika skladbami autorù, kteři Ti zejména přirostli $k$ srdci, ale misto toho konám slohová cvičení, abych Ti na nástroj, který neovládám, vyjádřil hluboký dík za Tvé skoro padesátileté spolehlivé prátelství. Ty jsi z těch, kteři si uměji čas pěkně rozdělit. Nepospíchají. Jdou. Chod' ještě dlouho v podzimu svého života, kdy se sice dny nápadně krátí, ale jsou s vrchu nejkrásnějši rozhledy, a hřej se na slunićku dobře vykonané činorodé práce, která poctivostí a závažností nepochybně překlene hranice, určené Ti prírodou. " ${ }^{446}$

K životnímu jubileu gratuloval Talich Šourkovi i v soukromém dopise, kde neméně vřele oceňuje Šourkovo věrné přátelství:

„právěv těchto dnech přiklusáš za mnou do té sedmašedesátky a jdu-li trochu pozdě nebo trochu brzo, nehled' na tu vnějš́i nepresnost a věř̆, že v staré neporušené oddanosti, která už trvá 44 let, Ti přeji dnes jako včera i jako zítra všecko nejkrásnější, co Ti život může dát.“"47

Dlouholetým a blízkým přítelem byl Otakaru Šourkovi i skladatel Josef Suk (1874-1935). Seznámili se prostřednictvím společného prítele, klavíristy Romana Veselého roku 1908. ${ }^{48}$ Oba dva navštěvovali Podskalskou filharmonii, jezdili spolu na výlety, trávili spolu se svými rodinami společné dovolené, navštěvovali se. Jejich přátelství ukončila až smrt Josefa Suka roku 1935. Jako ukázka vřelosti jejich vztahu může sloužit úryvek dopisu Josefa Suka Romanu Veselému, ve kterém Suk popisuje průběh společné dovolené se Šourkem:

„Drahý Rondo, tak uživáme prázdniny s Otou, [...] Včera jsme dělali tu poslední naši cestu přes Živohoušt’ a bylo krásně, dnes prší, tak půjdeme na houby. Mám silnou rýmu, tak piji bez hryzeni svédomi hodnè vína a kořalky; Ota mi trochu pomáhá, ale neumi to ještě dobře, ty a Ostrčil Jste v tom pokročilejší. "“99

O tom, jak si Suk Šourkova přátelství cenil, svědčí dedikace dvou Sukových skladeb Šourkovi, resp. jeho rodině. Josef Suk věnoval Šourkově ženě Olze při príležitosti narození jejich dvou dcer krátké klavírní skladbičky ze svých Ukolébavek, op. 33. Skladbu „Popěvek“, op. 33/2, dokončenou 13. 5. 1910, věnoval větou „Paní Olze a dět’átku“" paní Šourkové a právě narozené dceři Olze (narodila

45 Více o vztahu Otakara Šourka a Václava Talicha viz NOVÁ, Kateřina. Sondy do vztahu Václava Talicha a Otakara Šourka na pozadí jejich vzájemné korespondence, Hudební věda, r. 49 (2012), č. 3, s. 301-320, NOVÁ, Kateřina. Sondy do vztahu Václava Talicha a Otakara Šourka na pozadí jejich vzájemné korespondence v letech 1939 - 1956 (dokončení). Hudební věda, r. 50, č. 1-2, 2013, s. 145-178.

46 Viz pozn. 42, s. 137.

47 Talich, Václav. Šourek, Otakar, 13. 7. 1950, č. př. 88/98, uloženo v NM-MAD.

48 O přátelství se Sukem hovoří Šourek v rozhovoru, otištěním v časopise Rytmus, viz pozn. č. 5.

49 Cit. dle VOJTĚŠKOVÁ, Jana (ed.). Josef Suk. Dopisy o životě hudebnim i lidském. Praha: Editio Bärenreiter, 2005, s. 212. 
se 11. 5. 1910). ${ }^{50}$ Po narození druhé Šourkovy deery Vlady pak dedikoval Suk Olze Šourkové drobnost „K uzdravení“, op. 33/4 (myšleno po návratu paní Olgy $\mathrm{z}$ nemocnice). ${ }^{51}$ Jako hudební kritik stál Šourek vždy na Sukově straně, Sukovy tvorby si velice cenil, stejně tak jako aktivit Českého kvarteta, které pro Šourka představovaly ideál provádění české komorní hudby. Stejně tak Suk Šourkovi důvěřoval a svěřoval se mu se svými pochybnostmi a starostmi, jak dokládá tento úryvek ze Sukova dopisu:

„Můj drahý, prátelství Tvé, Rondovo [Roman Veselý] a Hoffmannovo [Karel Hoffmann] a vaše vira $v$ poctivost a ve výsledek mé práce byly mi vždy největš́i a nejčistši posilou $i v$ době, $k d y$ rítili se na mne drzi utrhovači z jedné strany a kdy strana druhá velmi vlažné činnost moji posuzovala. "52

Ze vzájemné korespondence se dozvídáme, že spolu sdíleli každodenní potíže a záležitosti, ale i diskutovali nad tvorbou Sukovou či Dvořákovou. Suk Šourkovi poskytoval cenné osobní vzpomínky na Dvořáka, měl živou starost o zdraví Šourkovy rodiny, a ačkoliv se mezi nimi někdy objevily drobné rozepře, Suk Šourka vždy považoval za ušlechtilého člověka. ${ }^{53} \mathrm{Na}$ závěr si dovolím ocitovat plné znění dopisu, který odeslal Josef Suk Šourkovi k jeho 50. narozeninám:

„Drahý príteli! Také již padesátka, a já ani nevím, jak Ti mám blahopráti, aby to nebylo tak obyčejné, jak se to často piše. Ty víš, jak Tě mám rád a jak si Tě vážim, jak jsem Ti vděčen, že vždy Jsi stál po mém boku, - v dobách těžkých i dobrých! - Jak nemám vyžadovati na Bohu, abys zůstal dlouho zdráv a stejně čilý a zaujatý pro vše dobré? Nuže vše dobré Tobě a celé rodině! A zároveň Jsi dokončil dillo o Dvořákovi, které jest a zůstane pokladem. Na to můžeš sám pohlížeti s hrdostí a sebevédomé. ${ }^{54}$

Dalším z Šourkových dobrých přátel byl světově uznávaný skladatel Bohuslav Martinů (1890-1959). ${ }^{55} \mathrm{O}$ Šourkově silné pozici na české hudební scéně svědčí množství žádostí a proseb, s nimiž se v té době již uznávaný skladatel na Šourka obrací. ${ }^{56}$ Martinů žádá Šourka v několika dopisech ${ }^{57} \mathrm{o}$ intervenci ve věci soutěže, resp. státní ceny, o kterou Martinů žádal. ${ }^{58}$ Martinů uvažoval o místu profesora

50 NOUZA, Zdeněk - NOVÝ, Miroslav. Josef Suk: tematický katalog skladeb. Praha: Editio Bärenreiter, 2005, s. 272.

51 Tamtéž, s. 279-280.

52 Viz pozn. č. 49 , s. 157.

53 Tamtéž, s. 200.

54 Tamtéž, s. 398.

55 V Šourkově pozůstalosti je uchováno na 20 rukopisných dopisů od Martinů, adresovaných Šourkovi v letech 1930-1955. Nejde o souvislou řadu dopisů, i tak ale ilustrují vztah mezi oběma významnými osobnostmi.

56 Více viz MAÝROVÁ, Kateřina. O čem si psali Otakar Šourek a Bohuslav Martinů. Harmonie, březen 2003, s. 19-21, duben 2003, s. 17-21.

Dopisy ze dne 25. 10. 1931, 26. 10. 1934, 3. 11. 1934, uloženy v NM-MAD pod č. př. 88/98.

58 V roce 1931 se Martinů přihlásil na konkurz Všesokolského sletu se skladbou Slavnostní předehra, v roce 1934 pak se skladbami Špalíček či Kvartet s orchestrem žádal o státní cenu a později se hlásil do soutěže o komorní skladbu, vypsanou Českým spolkem pro ko- 
kompozice na Pražské konzervatoři, rovněž v této záležitosti se na Šourka obrací s žádostí o podporu. Zde mu Šourek upřímně odmítá pomoci s vysvětlením, že o místo se uchází i jeho přítel z mládí, Jaroslav Křička, a není pro Šourka myslitelné podporovat $\mathrm{v}$ této věci někoho jiného. ${ }^{59}$ Velká část další vzájemné komunikace byla věnovaná další z Martinů žádostí na Šourka ${ }^{60}$ Martinů žádal Šourka o pomoc při vyřízení stipendia pro Martinů žačku Vítězslavu Kaprálovou (také ona sama Šourkovi v této záležitosti psala ${ }^{61}$ ). Kaprálová sice toho času pobývala v Pařǐži, stipendium jí ale už končilo a ona chtěla ve Francii zůstat i nadále. Šourek se snažil na ministerstvu intervenovat v Kaprálové prospěch, podrobně oba informoval o průběhu jejich záležitosti a Kaprálová nakonec skutečně stipendium získala.

\section{8. Šourek a jeho oponenti}

Rozdělení části hudební veřejnosti první republiky vyplývalo do velké míry $\mathrm{z}$ bývalých bojů o Dvořáka. $\mathrm{V}$ rozdělení stran lze spatřovat dle institucionální př́slušnosti okruh hudebníků-praktiků kolem pražské konzervatoře, tedy Suk, Novák, Talich, České kvarteto a další a okruh hudebních kritiků-teoretikủ z okolí katedry hudební vědy pražské Karlovy univerzity, tedy okruh se Zdeňkem Nejedlým v čele. Otakar Šourek, jak bude ukázáno dále, byl vnímán jako pevná část okruhu prvního, do kterého patřili jeho přátelé a který především sdružoval obdivovatele Antonína Dvořáka.

Prakticky po celý svůj veřejný život stál Otakar Šourek v názorové opozici vůči Zdeňku Nejedlému (1878-1962), levicovému intelektuálovi, historikovi a velkému propagátoru díla Bedřicha Smetany. V životech obou hudebních kritiků se však dají vysledovat zajímavé paralely. Oba byli v hudbě laikové, vystudovali původně jiný obor, než jakému se později věnovali a hudbu studovali soukromě. Oba byli veřejně aktivní hudební kritici. Oba dva zasvětili své životy propagaci, obhajobě a výkladu odkazu českých hudebních velikánů - Nejedlý Smetanovi, Šourek Dvořákovi. A právě z této poslední paralely možná vyvěrá i jejich vzájemná nevraživost. Již od bojů o Dvořáka stáli tito dva kritici na opačné straně názorového spektra a na těchto pozicích setrvali do konce svého veřejného působení - např̀ v tzv. Sukově afére, ve sporu Nováka s Ostrčilem i v dalších př́ípadech. Ve své korespondenci s přáteli si Šourek či jiní občas neodpustili narážku na Nejedlého, i když otevřená kritika či dokonce nepřátelství nahlas vysloveno nebylo. Např́íklad v dopise rodinné príitelkyni Miladě Havlové z dubna

morní hudbu v Praze. Šourek byl členem Sokolské obce, zasedal v porotě pro státní cenu a v Komorním spolku se rovněž angažoval. V prvých dvou př́ípadech Martinů pomoci nemohl, ve třetím Martinů cenu získal.

59 Viz pozn. 56, s. 21.

60 Celkem 6 dopisů: ze dne 25. 10. 1938, 8. 11. 1938, 13. 11. 1938, 5. 12. 1938, 22. 12. 1938, 20.1. 1939.

61 Kaprálová, Vítězslava. Šourek, Otakar, 16. 6. 1937, 5. 8. 1937, 14. 9. 1937, 22. 9. 1937. 
1948 Šourek sám připouští, že „ideologicky nepatř̌i v hudbě pod učení nejvyššího pána!“62 V dopise Miloši Bezděkovi z roku 1946 pak zase Nejedlého nazývá „rudým dědkem“ či ,prof. Peklem“. ${ }^{63}$

Dalším Šourkovým protivníkem na poli hudební žurnalistiky byl Nejedlého žák a spolupracovník, estetik Josef Bartoš (1887-1952), působící na stránkách časopisu Smetana, vedeným Nejedlým. Se Šourkem polemizoval Bartoš během bojů o Dvořáka, osobně přišli do konfliktu poprvé po vydání Bartošovy publikace „Antonín Dvořák: kritická studie“64 v roce 1913. Bartoš ve své studii označuje Dvořáka za skladatelský zjev neoriginální, primitivní. Šourek tento závěr samozřejmě odmítá a namítá, že Bartoš svůj názor na Dvořáka změnil pod vlivem Nejedlého.$^{65}$ Důvodem dalšího sporu, který vypukl v roce 1921, byl objev v dvořákovské chronologii. Richard Veselý v poznámce k programu České filharmonie napsal, že správné zařazení Symfonie F dur, op. 76 je až objevem Otakara Šourka z roku 1917. Vůči tomu se Bartoš ohrazuje ${ }^{66}$, nebot' již on ve své publikaci z roku 1913 nejasnosti kolem datace symfonie vysvětluje. Šourek argumentuje, že své informace nečerpal z Bartošova textu, nýbrž z textu mnohem staršího, otištěného v časopisu Die Musik. Zásluhu o správnost datace mají tedy oba stejnou - žádnou. ${ }^{67}$

Během prvních svobodných let samostatné Československé republiky se Šourek dostal do sporu také s Janem Maria Augustou (1897-1939), hudebním kritikem a žurnalistou, působícím v časopise Hudební revue a později Dalibor. Stalo se tak kvůli sporu o nového dirigenta České filharmonie na přelomu let 1918/19. Augusta ve svém časopise Šourka, který prosazoval Václava Talicha, několikrát slovně napadl a osočoval jej z klikaření, stejně tak jako celou Uměleckou besedu, Josefa Suka, Václava Talicha a mnoho dalších lidí. O Šourkovi tvrdil, že jej na post hudebního recenzenta novin Venkov dosadila jeho „strana“ a on tam nyní „provozuje pravý teror"68 a „,nutí brutálně kde koho uvěřiti, že dirigování Talichovo je ,prímo objevem “"“69

\section{Shrnutí - význam Otakara Šourka pro českou hudební kulturu}

Předkládaný text si kladl za úkol upozornit na šíři aktivit Otakara Šourka. Jeho místo předního znalce života a díla Antonína Dvořáka je neotřesitelné, nicméně

\footnotetext{
62 Šourek, Otakar. Havlová, Milada, Praha, 13. 4. 1948. Uloženo v NM-MAD, č. př. 88/98.

63 Šourek, Otakar. Bezděk, Miloš, Praha, 2. 7. 1946. Uloženo v NM-MAD, č. př. 88/98.

64 BARTOŠ, Josef: Antonín Dvořák: kritická studie. Praha: J. Pelcl, 1913.

65 ŠOUREK, Otakar: Nová kniha o Dvořákovi. Hudebni revue, 1915, r. 8, č. 2, s. 59-71.

66 BARTOŠ, Josef: O dvořákovskou chronologii. Smetana, r. 11, č. 7-8, 18. 11. 1921, s. 130 131.

67 ŠOUREK, Otakar: O dvořákovskou chronologii. Smetana, r. 11, č. 9-10, 30. 12.1921, s. $155-156$.

68 AUGUSTA, Jan Maria: Mosaika. Dalibor, r. 36, č. 4-5, 22. 3. 1919, s. 42.

69 Tamtéž.
} 
nevystihuje zdaleka vše, co Šourek pro český hudební život znamenal. „Otakar Šourek [...] patři k nejvýraznějším postavám soudobého českého hudebního života. "70 Takové bylo dobové hodnocení jeho významu. Jakožto přední postava českého hudebního života nejen první republiky, ale také let válečných a poválečných, Šourek skrze své pozice v četných spolcích a institucích spoluvytvářl hudební život, do velké míry jej ovlivňoval a díky své kritické činnosti i v denních listech měl dopad také na nehudební, širokou veřejnost. Jakožto přední a uznávaný znalec díla Antonína Dvořáka pak do velké míry utvářel „mediální obraz“ tohoto skladatele.

Kateřina Nová (katerina_nova@nm.cz), Národní muzeum, Muzeum Antonína Dvořáka.

\section{ABSTRACT \\ OTAKAR ŠOUREK - UNDERVALUED FIGURE OF CZECH MUSICAL LIFE}

The presented short study deals with Otakar Šourek, the author of the most extensive monograph on Antonín Dvořák to date. However he was the front connoisseur of the life and work of the composer, Šourek played even more significant role in the musical life of his period. He worked for numerous important music institutions and wrote music reviews, articles and studies for many journals and magazines, as well as books, dealing with Dvořák's student, performer and contemporaries. The text strives to evaluate Šourek's position amid the musical life of the time and emphasize his significance in Czech music history.

\section{Key words}

music criticism, music, Otakar Šourek, Antonín Dvořák, musical life, music institutions

\section{Bibliography}

AUGUSTA, Jan Maria: Mosaika. Dalibor, r. 36, č. 4-5, 22. 3. 1919, s. 42.

BAJEROVÁ, Blanka. V. Novák, J. Suk a Podskalská filharmonie. [online]. Dostupné z: <http:// www.suksociety.cz/odbisp/CL bajerova.htm>.

BARTOŠ, Josef: Antonín Dvoŕák: kritická studie. Praha: J. Pelcl, 1913.

BARTOŠ, Josef: O dvořákovskou chronologii. Smetana, r. 11, č. 7-8, 18. 11. 1921, s. 130-131.

BURGHAUSER, Jarmil. Antonín Dvořák. Tematický katalog. Bibliografie, přehled života a dílo.

2. vyd. Praha: SNKLHU, 1960.

DVOŘÁK, Antonín a ŠOUREK, Otakar, ed. Antonín Dvořák přáteliom doma. Praha: Melantrich, 1941.

HALLOVÁ, Markéta. 75 let Společnosti Antonína Dvořáka, Hudební rozhledy, 2006, r. 59, č. 3, S. 45.

HOŘEJŠ, Antonín. Jubileum Otakara Šourka. Hudebni rozhledy. 1953, r. 6, č. 14, s. 654.

Jbk. K jubileu Otakara Šourka. Rytmus, 1943-1944, r. 9, č. 1, s. $2-7$.

LÖWENBACH, Jan. Dvořákův životopisec. Tempo: Listy Hudební matice. 1933, r. 13, č. 2, s. 35-40. 
MAÝROVÁ, Kateřina. O čem si psali Otakar Šourek a Bohuslav Martinů. Harmonie, březen 2003, s. 19-21, duben 2003, s. 17-21.

MIKOTA, Václav, ed. Hudba a národ. V Praze: Svaz českých knihkupců a nakladatelů, 1940.

NOUZA, Zdeněk - NOVÝ, Miroslav. Josef Suk: tematický katalog skladeb. Praha: Editio Bärenreiter, 2005.

NOVÁ, Kateřina. Dvořákův jubilejní rok 1941. Musicalia, 2014, r. 6, č. 1-2, s. 39-52.

NOVÁ, Kateřina. Novináŕ a recenzent Otakar Šourek. Musicalia, 2011, r. 3, č. 1-2, s. 79-84.

NOVÁ, Kateřina. Sondy do vztahu Václava Talicha a Otakara Šourka na pozadí jejich vzájemné korespondence. Hudební véda, 2012, r. 49, č. 3, s. 301-320.

NOVÁ, Kateřina. Sondy do vztahu Václava Talicha a Otakara Šourka na pozadí jejich vzájemné korespondence v letech 1939-1956 (dokončení). Hudební věda, 2013, r. 50, č. 1-2, s. 145-178.

OTTLOVÁ, Marta. The"Dvořák Battles" in Bohemia: Czech Criticism of Antonín Dvořák, 19111915. In: Rethinking Dvoř́k. Views from Five Countries. BEVERIDGE, David R. (ed.). Oxford: Clarendon Press, 1996.

PEČMAN, Rudolf. Útok na Antonína Dvořáka. Brno: Filozofická fakulta Masarykovy univerzity, 1992.

SKÁCEL, František. Sedmdesát let Umělecké besedy. 1863-1933. Praha: Umělecká beseda, 1933.

SLOMINSKY, Nicholas, ed.: Baker's Biographical Dictionary of Musicians, Vol. 5. New York: Schirmer Reference, 2001, s. 704.

ŠOUREK, Otakar, ed. Smetanova „Má vlast“: její vznik a osudy. Praha: Topičova edice, [1940].

ŠOUREK, Otakar, ed. Václav Talich: život a práce: soubor statí. Praha: Hudební matice Umělecké besedy, 1943.

ŠOUREK, Otakar. Antonín Dvořák. Praha: Mánes, 1929.

ŠOUREK, Otakar. Dvoř́kovy skladby komorní: charakteristika a rozbory. Praha: Hudební matice Umělecké besedy, 1943.

ŠOUREK, Otakar. Dvoř́ákovy skladby orchestrálni: charakteristika a rozbory. [Svazek] I., Koncerty - serenády - suity - nokturna - rhapsodie - slovanské tance - legendy - symfonické variace - scherzo capriccioso - skladby drobné. Praha: Hudební matice Umělecké besedy, 1944.

ŠOUREK, Otakar. Dvořákovy skladby orchestrální: charakteristiky a rozbory. [Svazek] II., Skladby programní. Ouvertury operni - ouvertury koncertni - symfonické básně. Praha: Hudební matice Umělecké besedy, 1946.

ŠOUREK, Otakar. Dvoŕák's Werke: Ein vollständiges Verzeichnis in chronologischer, thematischer Anordnung = Skladby Dvoŕákovy: Úplný seznam chronologický, thematický a systematický. Berlin: Simrock, [1917].

ŠOUREK, Otakar: Život a dílo Antonína Dvořáka. Praha: Hudební Matice Umělecké besedy, $1922-1933.4 \mathrm{sv}$.

ŠOUREK, Otakar. Jos. Suk o svém tvưrčím vývoji. Tempo: Listy Hudební matice, 1934, r. 13, č. 5, s. $142-145$.

ŠOUREK, Otakar. Leoš Janáček: Výlety páně Broučkovy: Rozbor. Praha: Hudební matice Umělecké besedy, 1920.

ŠOUREK, Otakar. Rudolf Karel: Variace v životě i díle. Vydání 1. Praha: Hudební matice Umělecké besedy, 1947.

ŠOUREK, Otakar. Skladby Josefa Suka. Hudební revue, r. 7, č. 4-5, leden - únor 1914, s. 186-198.

ŠOUREK, Otakar. Skladby Vítězslava Nováka, Hudební revue, r. 3, č. 10, prosinec 1910, s. 507516.

ŠOUREK, Otakar. Stopami Sukova Epilogu. Tempo: Listy Hudebni matice, 1946, r. 18I, č. 2-3, s. 35-39 a č. 4-5, s. 120-124.

ŠOUREK, Otakar. Sukovy melodramatické pohádky. Hudební revue, 1912, r. 5, č. 7, s. 312.

ŠOUREK, Otakar. Tematický rozbor Symfonie A dur O. Ostrčila, Smetana, 1906, r. 1, č. č. 6, 1. 3. 1906, s. 73-79.

ŠOUREK, Otakar: Nová kniha o Dvořákovi. Hudební revue, 1915, r. 8, č. 2, s. 59-71.

ŠOUREK, Otakar: O dvořákovskou chronologii. Smetana, r. 11, č. 9-10, 30. 12.1921, s. 155-156. 
ŠTĚDROŇ, Bohumír. Šourek, Otakar. In KOL. RED.: Československý hudebni slovnik osob a institucí. Svazek 2. Praha: Státní hudební vydavatelství, 1965, s. 714-715.

TALICH, Václav. Úvahy, projevy a statě. Beroun: Okresní muzeum Beroun, 1983.

TYRRELL, John. Šourek, Otakar. In SADIE, Stanley, ed. The New Grove. Vol. 17. London: Macmillan Publisher, 1980, s. 753-754.

VEČEǨA, Pavel. Národní souručenství, in: Politické strany: vývoj politických stran a hnutí v českých zemich a Československu v letech 1861-2004, Malíŕ, Jiří a kol. Brno: Doplněk, 2005, s. 1091-1103.

VOJTĚŠKOVÁ, Jana (ed.). Josef Suk. Dopisy o životě hudebním i lidském. Praha: Editio Bärenreiter, 2005.

Výroční státní ceny pro hudební umění a teorii. Tempo: Listy Hudební matice, r. 9, č. 3, 20. 11. 1929, s. 122. 